\title{
A novel 27 kDa lipoprotein antigen from Mycobacterium bovis
}

\author{
F. Bigi, ${ }^{1}$ C. Espitia, ${ }^{3}$ A. Alito, ${ }^{2}$ M. Zumarraga, ${ }^{1}$ M. I. Romano ${ }^{1}$, S. Cravero ${ }^{1}$ \\ and A. Cataldi ${ }^{1}$
}

Author for correspondence: A. Cataldi. Tel: +54 1621 1447. Fax: +54 14812975.

e-mail: angel@bminta.edu.ar
1,2 Instituto de
Biotecnología, PO Box $77^{1}$ and Instituto de
Patobiologia2, CICV-INTA,
Castelar, Argentina
3 Departamento de Inmunologia, Instituto de Investigaciones Biomédicas, UNAM, México DF, Mexico

\begin{abstract}
A novel Mycobacterium bovis antigen was identified from an expression library using sera from naturally infected cattle. The Escherichia coli recombinant clone expressed a 27 kDa protein, named P27. A rabbit serum against the recombinant antigen recognized a protein of $27 \mathrm{kDa}$ in cellular extracts from $M$. bovis and $M$. tuberculosis. No protein was recognized in the culture supernatant. Sequence analysis indicated that P27 has a molecular mass of $24 \mathrm{kDa}$, showing a characteristic signal sequence for lipoprotein modification (a signal peptidase type II site). The gene is identical to a gene identified in the $\boldsymbol{M}$. tuberculosis genome sequencing project. Cellular fractionation experiments suggested that $\mathrm{P27}$ is an integral membrane protein. The antigen was recognized by individual sera and peripheral blood mononuclear cells (PBMC) from diseased cattle. PCR experiments with specific primers directed to the P27 structural gene indicated that it is only present in the $M$. tuberculosis species complex. In conclusion, a novel immunogenic lipoprotein in $\boldsymbol{M}$. bovis/M. tuberculosis has been identified. The results presented here and elsewhere suggest that mycobacterial lipoproteins should be considered in the design of new recombinant vaccines and diagnostic methods.
\end{abstract}

Keywords: Mycobacterium tuberculosis, Mycobacterium bovis, lipoproteins, antigen, membranes

\section{INTRODUCTION}

The identification and characterization of individual antigenic proteins are essential to the understanding of the pathogenic mechanisms of mycobacteria and the immune response against them. This achievement may also contribute to understanding the pathogenesis of other intracellular bacterial infections in which cellular immunity is also involved. Such antigens are needed for the design of new diagnostic tests and subunit vaccines. However, the extremely long doubling time and the pathogenicity of mycobacteria have delayed for years the identification of antigens and virulence factors. Application of both molecular biology and immunological tools, such as gene cloning and monoclonal antibodies, has made an important contribution to our knowledge of $M$. tuberculosis and M. leprae antigens,

Abbreviation: PBMC, peripheral blood mononuclear cells.

The EMBL accession number for the sequence reported in this paper is AJ000500. and of the cellular and humoral immune responses against them (Ivanyi et al., 1985; Young et al., 1985). Recent research has focused on species-specific antigens because some of the first mycobacterial antigens identified and cloned, the so-called stress proteins, are broadly present in other pathogenic bacteria (Young et al., 1990).

Numerous mycobacterial antigens have been described (Young et al., 1992); many of them have been expressed in Escherichia coli and identified by immune cells and antibodies. However, no clear immunodominant antigen covering all the stages of the disease has been found (Verbon et al., 1990; Cataldi et al., 1994). This fact has caused research to be directed to a mix of antigens instead of a unique protective or dominant antigen.

Mycobacteria secrete several proteins (Abou-Zeid et al., 1988; Andersen et al., 1991; Wiker et al., 1991), many of which are antigens. Secreted proteins are thought to be essential in protective immunity, because a mix of secreted proteins may confer protection in mice against 
a challenge with virulent strains (Orme, 1988; Pal \& Horwitz, 1992). There is an increasing interest in these antigens to prepare new generation anti-TB vaccines (Orme 1988; Pal \& Horwitz, 1992; Andersen, 1994) However, certain non-secreted proteins, such as membrane-associated, cell-wall-associated or cytoplasmic (Andersen \& Brennan, 1994) proteins, have also been reported to be antigens. Some membrane protein antigens have been well studied. A $19 \mathrm{kDa}$ membrane lipoglycoprotein and a $16 \mathrm{kDa}$ protein or MMP (Lee et al., 1991) are the most studied M. tuberculosis membrane antigens (Ashbridge, 1989; Collins et al., 1990; Faith et al., 1991; Booth et al., 1993; Prestidge et al., 1995).

We have identified a novel antigen that reacted with a pool of sera of $M$. bovis-infected cattle. This antigen, whose characterization we report here, is a $27 \mathrm{kDa}$ hypothetical lipoprotein.

\section{METHODS}

Bacterial strains, media and cloning vectors. $M$. bovis AN5 and $M$. tuberculosis $\mathrm{H} 37 \mathrm{Rv}$ were used to prepare whole extracts and culture supernatants. Clinical isolates were obtained from Nora Morcillo (Hospital Cetrángolo, Argentina). Mycobacteria were cultivated in Middlebrook $\mathrm{M} 7 \mathrm{H} 9$ liquid medium (Difco). E. coli XL1-Blue (Stratagene) was used as the main recipient for recombinant plasmids. It was grown in LB medium (Sambrook et al., 1989). pBluescript KS II (Stratagene) was used as the cloning vector.

Mycobacterial DNA preparation. DNA from M. tuberculosis, M. bovis, M. vaccae, M. paratuberculosis, M. avium, $M$. kansasii and M. smegmatis was prepared according to van Soolingen et al. (1991). DNA from M. marinum, M. gordonae and M. scrofulaceum was obtained from Philip Suffys (Fundacion Oswaldo Cruz, Rio de Janeiro, Brazil).

$\boldsymbol{M}$. bovis genomic library and screening. The construction and screening of a $M$. bovis genomic library in $\lambda$ ZAP (Stratagene) has been described previously (Bigi et al., 1995).

SDS-PAGE and Western blotting. Samples were boiled in loading buffer $(2 \%, \mathrm{w} / \mathrm{v}, \mathrm{SDS}, 0 \cdot 125 \mathrm{M}$ Tris $/ \mathrm{HCl}, \mathrm{pH} 6 \cdot 8$, $1 \%, \mathrm{v} / \mathrm{v}, 2$-mercaptoethanol, $0.02 \%$ bromophenol blue, $10 \%$, $\mathrm{v} / \mathrm{v}$, glycerol). Proteins $(50 \mu \mathrm{g})$ were separated by electrophoresis in $12 \%$ (w/v) SDS-PAGE gels by the technique of Laemmli (1970) and electrotransferred onto a nitrocellulose sheet by the semi-dry method (Kyhse-Andersen, 1984). Transfer yield was visualized by transient staining with Ponceau Rouge. Nitrocellulose membranes were incubated with the first antibody overnight at $4{ }^{\circ} \mathrm{C}$ and with an alkaline phosphatase-conjugated secondary antibody for $2 \mathrm{~h}$ at $37^{\circ} \mathrm{C}$. The colour reaction was developed for $30 \mathrm{~min}$ by the addition of 5 bromo-4-chloro-3-indolyl phosphate and nitro blue tetrazolium as substrates. When directed against E. coli antigens, the serum was absorbed of antibodies against $E$. coli by preincubation for $1 \mathrm{~h}$ at $37^{\circ} \mathrm{C}$ with non-transformed $E$. coli extract ( $1 \mathrm{mg}$ protein $\left.\mathrm{ml}^{-1}\right)$.

Subcellular fractionation. A 4-week-old M. bovis $250 \mathrm{ml}$ culture was used for cell fractionation. Culture supernatant and cells were separated by centrifugation at $10000 \mathrm{~g}$ for $20 \mathrm{~min}$. Proteins in culture supernatant were precipitated with $10 \%(\mathrm{v} / \mathrm{v})$ trichloroacetic acid. The precipitated material was resuspended in $1 / 20$ of the original volume in PBS. Sonicated cell extract was obtained by resuspending the cells in $25 \mathrm{ml}$ PBS. The suspension was sonicated in an ice bath for $10 \mathrm{~min}$ in a Branson sonifier (model 250/450). The lysate was cleared by centrifugation at $20000 \mathrm{~g}$ for $15 \mathrm{~min}$. The supernatant was centrifuged at $100000 \mathrm{~g}$ for $2.5 \mathrm{~h}$. The insoluble pellet (membranes) was washed with PBS and resuspended in $2 \mathrm{ml}$ distilled water. An estimate of the purity of the membrane fraction was determined by assaying for a membrane enzyme marker, lactate dehydrogenase. The specific activity of the lactate dehydrogenase in the membrane fraction was tenfold higher than in the cytosolic fraction. The membrane fraction was processed by Triton $\mathrm{X}-114$ phase separation according to Bordier (1981).

T cell reactivity assay. Bovine peripheral blood mononuclear cells (PBMC) were prepared from heparinized blood by FicollPaque (Pharmacia) centrifugation and washed three times in r.p.m.I1640 (Life Technologies). Cells were counted and resuspended $\left(2 \times 10^{5}\right.$ per well) in r.p.m.I1640 supplemented with $1 \%(\mathrm{w} / \mathrm{v}$ ) penicillin/streptomycin, $2 \mathrm{mM}$ L-glutamine, $20 \mathrm{mM}$ HEPES and $10 \%(\mathrm{v} / \mathrm{v})$ heat-inactivated calf foetal serum. E. coli(pMBA21) extracts were added at a concentration of $10 \mu \mathrm{g} \mathrm{m}^{-1}$ and incubated for $24 \mathrm{~h}$ at $37^{\circ} \mathrm{C}$ in $5 \%$ $(\mathrm{v} / \mathrm{v}) \mathrm{CO}_{2}$. The culture supernatant was harvested by centrifugation and bovine interferon- $\gamma$ was measured by ELISA using a commercial kit (Iddexx).

Sera. Cattle sera were obtained from cattle with macroscopical tuberculosis lesions confirmed by $M$. bovis culture as described previously (Cataldi et al., 1994) and used at 1/100 dilution.

To obtain anti-27-kDa-protein-specific serum, E. coli recombinant extracts $(100 \mu \mathrm{g})$ were loaded in a large $10 \mathrm{~cm}$ well and developed onto a SDS-PAGE gel. The gel region where the recombinant band migrated (as determined by Western blotting) was excised, crunched, mixed with Freund's incomplete adjuvant and injected in three doses separated by 2week intervals into one rabbit.

Sequencing. Plasmid DNA, prepared using the Wizard Minipreps kit (Promega), was used as template. Sequencing was performed using T3, T7 and sequence-deduced primers that initiated dideoxy nucleotide chain-termination reactions (Sanger et al., 1977). The Femtomol sequencing kit (Promega) and $6 \%$ polyacrylamide gels with $30 \%(\mathrm{w} / \mathrm{v})$ formamide were used.

PCR. Primers 5' GACGGTCAACGGCAAGATCCC $3^{\prime}$ and 5' TGCGCTGCGACCACAAATC 3' were used in amplifications. The amplification conditions were: an initial denaturation step at $94^{\circ} \mathrm{C}$ for $2 \mathrm{~min}$, followed by 30 cycles of $94^{\circ} \mathrm{C}$ for $1 \mathrm{~min}$ (denaturation), $55^{\circ} \mathrm{C}$ for $1 \mathrm{~min}$ (annealing) and $72{ }^{\circ} \mathrm{C}$ for $1 \mathrm{~min}$ (extension). The amplification products were detected in agarose gels.

Sequence analysis. Sequence analyses were performed using DNA Strider 1.2 software (Marck, 1988). Nucleotide sequence searches were performed using the EMBL database. Homology determinations were performed with Laser gene software (DNASTAR).

Other molecular genetics procedures. Standard procedures (Sambrook et al., 1989) were used for the preparation of plasmid DNA, restriction enzyme digestions and ligations.

\section{RESULTS}

\section{Molecular cloning of the gene encoding the $27 \mathrm{kDa}$ protein}

We identified a clone that reacted with a pool of sera from M. bovis-infected cattle by screening an $M$. bovis library constructed in $\lambda$ ZAP. Details of the library 


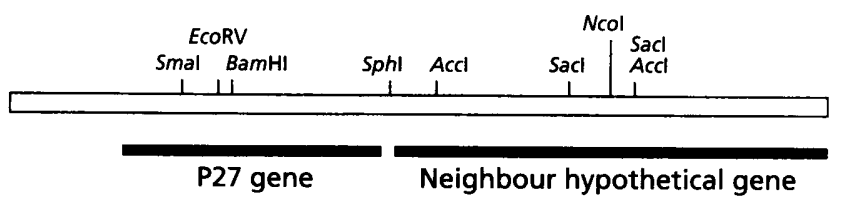

Fig. 1. Schematic representation of the pMBA21 $2 \mathrm{~kb}$ insert.

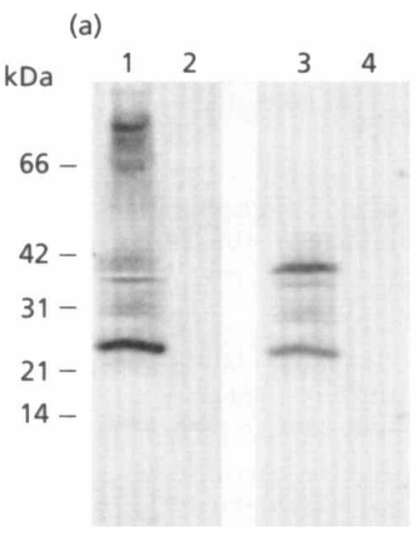

(b)

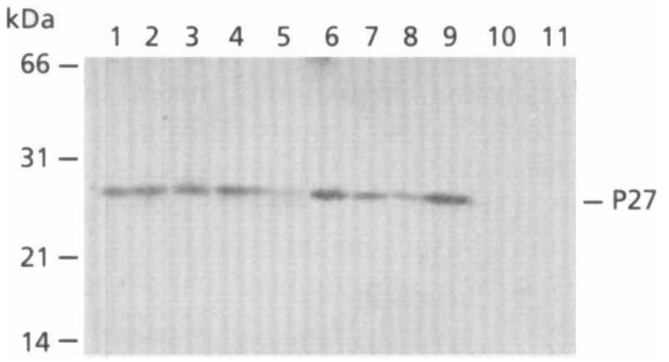

Fig. 2. (a) P27 expression in E. coli. Western blot using cattle pool serum (lanes 1 and 2) or rabbit anti-P27-specific serum (lanes 3 and 4). Lanes 1 and 3, E. coli DH5 $\alpha$ (pMBA21); lanes 2 and $4, E$. coli $\mathrm{DH} 5 \alpha$. (b) Production of P27 by different mycobacteria. Western blot using rabbit anti-P27 specific sera. Lanes: $1, M$. bovis An5; $2, M$. tuberculosis H37Rv; 3, $M$. bovis $1372 ; 4, M$. tuberculosis 124; 5 , $M$. tuberculosis F15; $6, M$. bovis $142 ; 7, M$. bovis t991; 8 , M. bovis BCG; $9, M$. microti; $10, M$. smegmatis; $11, M$. paratuberculosis.

construction and screening were published previously (Bigi et al., 1995). The recombinant plasmid pMBA21 was obtained from this clone by the automatic plasmid excision process of $\lambda Z A P$. It contained an insert of $2.0 \mathrm{~kb}$ and was characterized by restriction mapping (Fig. 1).

Cell extracts of E. coli(pMBA21) were prepared to study the size and level of expression of the recombinant protein. The pool of cattle sera was incubated with cell extracts of $E$. coli(pMBA21) recognizing a protein band of $27 \mathrm{kDa}$ (Fig. 2a, lane 1). Another protein band of $35 \mathrm{kDa}$ was also detected. Other minor bands were also recognized. The $27 \mathrm{kDa}$ protein and the other proteins were not recognized in non-recombinant E. coli. Expression of the gene encoding the $27 \mathrm{kDa}$ protein seems

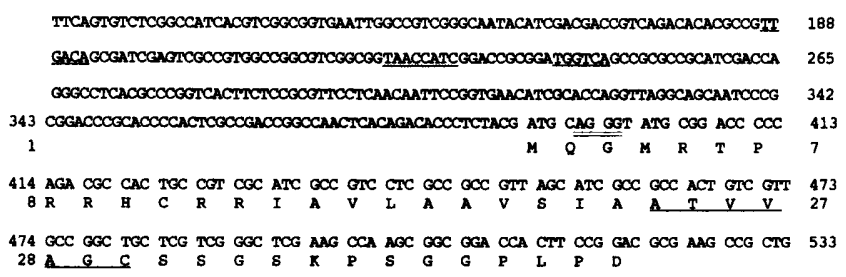

Fig. 3. Main features of the of P27 coding region. The deduced amino acid sequence is shown below the nucleotide sequence. The -35 and -10 putative promoter elements are shown by plain and wavy underlining, respectively. The ribosome-binding site is shown by double underlining. Underlined amino acids 24-30 represent the consensus site for lipoprotein modification.

to be, at least partially, under the control of the lac promoter because there is an increase in production of the protein on the addition of IPTG (data not shown).

To obtain anti-27-kDa-protein-specific serum, the recombinant $E$. coli protein band was excised from polyacrylamide gels and the pieces of gel were injected into rabbits. The serum obtained reacted with a protein of $27 \mathrm{kDa}$ in E. coli(pMBA21) cell extracts (Fig. 2a, lane 3). The protein was named P27. A $35 \mathrm{kDa}$ protein band was also recognized by the rabbit sera. The serum recognized P27 in $M$. bovis cell extracts but not in culture supernatants. P27 is also produced by M. bovis BCG, and $M$. tuberculosis reference strains and clinical isolates (Fig. 2b), but not by M. smegmatis. The rabbit anti-P27 serum specifically precipitated P27 produced by $M$. bovis (data not shown) and solubilized by Triton X-114 (see below). Some signs of toxicity produced by P27 expression were noticed during the cloning experiments. For example, pMBA21 and derivatives expressing the full protein in $E$. coli yield lower amounts of plasmid DNA than non-expressing derivatives.

To locate the gene encoding P27 in pMBA21, shorter fragments of pMBA21 insert, obtained by restriction enzyme digestion, were subcloned in pBluescript KSII. E. coli cell extracts carrying the shortened pMBA21 derivatives were prepared and the presence of P27 was detected by Western blotting using anti-P27 serum. The subcloning indicated that the gene is located between the start of the insert and the AccI site in the insert. As a consequence, we continued to work with a shortened derivative of pMBA21 that was obtained by digestion with $A c c \mathrm{I}$ and religation (plasmid pMBA23) rendering an insert of $1 \mathrm{~kb}$.

\section{Sequence analysis}

The sequence of the pMBA23 insert (Fig. 3) revealed only one ORF of the required size and position. There are two probable start codons, three codons apart from each other. No clear ribosome-binding site was present upstream of the first start codon, but an AGGG motif was found 5 bases before the second ATG, favouring this codon as the true start codon. The ORF encodes a 
(a)

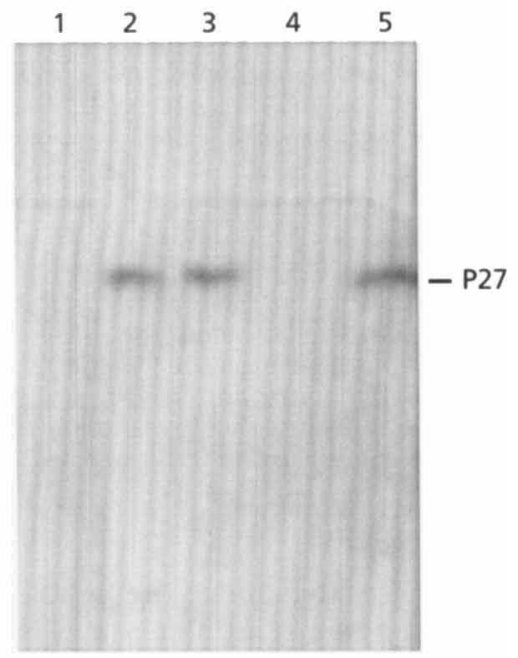

(b)

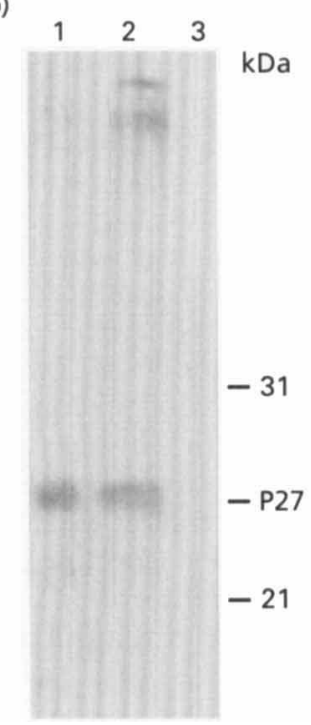

Fig. 4. Fractionation of $M$. bovis An5 cell extract. Western blot using rabbit anti-P27-specific serum. (a) Lanes: 1, M. bovis An5 culture supernatant; $2, M$. bovis An5 total cell extract; 3 , $20000 \mathrm{~g}$ supernatant; 4, $100000 \mathrm{~g}$ supernatant; $5,100000 \mathrm{~g}$ pellet. (b) Lanes: 1, $M$. bovis An5 total cell extract; 2, detergent phase of Triton X-114 fractionation; 3, aqueous phase of Triton $\mathrm{X}-114$ fractionation.

protein of 236 aa with a molecular mass of $24532 \mathrm{Da}$. -35 promoter elements were identified at 187-192 (TTGACA) and 242-247 (TGGTCA); a - 10 element was identified at 224-231 (TAACCATC). The overall $\mathrm{G}+\mathrm{C}$ content was $65 \%$. The sequence of pMBA23 suggested that another ORF exists downstream from the gene encoding P27. This fact was further corroborated by analysing the sequence of a cosmid from the $M$. tuberculosis genome sequencing project (see below).

Analysis using the Prosite database revealed that P27 contained a characteristic motif for lipoprotein modifcation (a signal peptidase type II site). The consensus

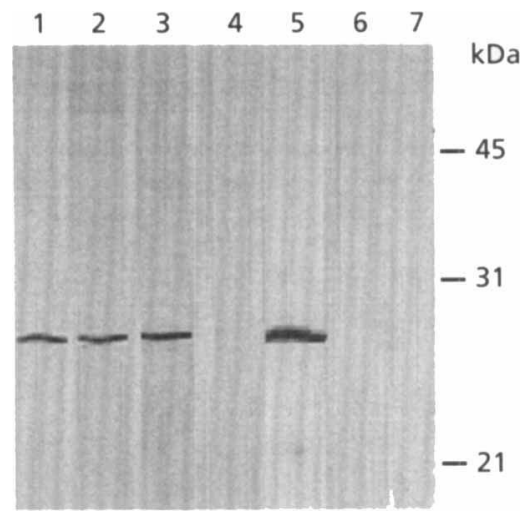

Fig. 5. Recognition of $E$. coli recombinant $P 27$ by cattle sera. Lanes 1-7, sera from infected cattle were used at 1/100 dilution.

signature, ATVVAGC, is found from aa 24 to 30. Hydrophobicity analysis, according to the Kyte \& Doolittle algorithm (Kyte \& Doolittle, 1982), indicated that P27 contains four hydrophobic regions (aa 10-30, $55-70,100-120$ and $140-150)$. This sequence showed perfect homology to a gene of a hypothetical protein detected in the $M$. tuberculosis genome sequencing project (accession no. Z80108, CDS MTCY21B4.28c). Another $M$. tuberculosis gene deduced from the $M$. tuberculosis genome sequencing project is partially homologous to P27. The putative $26.4 \mathrm{kDa}$ product of this gene is postulated to be a transmembrane protein (accession no. Q11049) with four hydrophobic regions and lacking the consensus signature for a lipoprotein. Homology is stronger in some portions of these two proteins, especially from aa 141 to 152 (GLANVLANFADA). Lesser degrees of homology were found with a copper-containing nitrite reductase from Rhizobium hedysari (accession no. Q60214) and a cow Tau protein (accession no. L34940).

\section{Subcellular localization of P27}

To determine the localization of P27, different subcellular fractions were prepared from M. bovis (Fig. 4). The protein was found in the membrane fraction. It was also found in the membrane fraction of $M$. tuberculosis (data not shown). Phase separation with Triton X-114 was used to determine the degree of P27 association with the membrane. It was found in the detergent phase, suggesting that P27 is an integral membrane protein. The membrane fraction was submitted to 2-D gel electrophoresis and anti-P27 serum recognized a single spot, indicating that it is a unique protein molecule (not shown). The isoelectric point of $6 \cdot 0$, determined from the 2-D gel, is in good agreement with the theoretical isoelectric point of 5.7 determined by Laser Gene software.

\section{Immune recognition}

The recognition frequency of this protein by serum of infected cattle was studied by Western blotting. The E. 


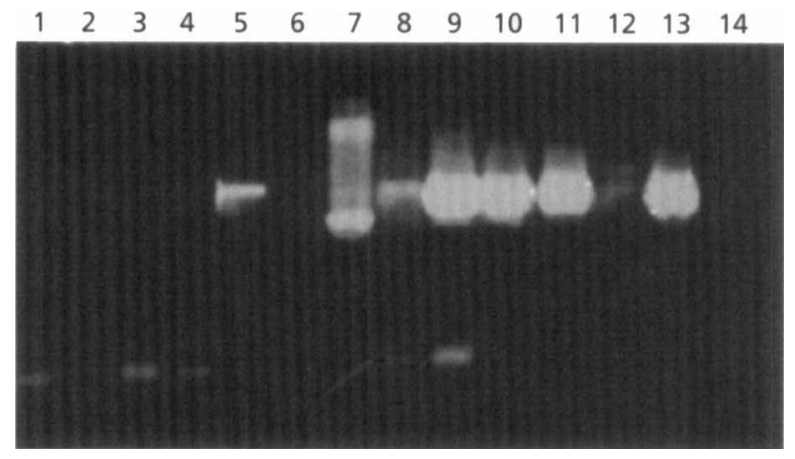

Fig. 6. $P C R$ to detect the gene encoding $P 27$ in different mycobacteria. Amplification products were analysed on $0.8 \%$ agarose gels. Ten nanograms of genomic DNA was used as template. Lanes: $1, M$. smegmatis; $2, M$. aureum; $3, M$. gordonae; 4, $M$. scrofulaceum; $5, M$. avium; $6, M$. marinum; 7 , $M$. kansasii; $8, M$. vaccae; $9, M$. bovis AN5; $10, M$. tuberculosis H37Rv; $11, M$. bovis $142 ; 12, M$. paratuberculosis; $13, M$. bovis BCG; 14, negative control.

coli recombinant P27 protein was recognized by 4 of 7 sera of infected cattle (Fig. 5). Cattle sera were first absorbed of anti-E. coli antibodies. Sera from healthy cattle showed no reaction (data not shown).

$T$ cell recognition of $\mathrm{P} 27$ was assayed with PBMC from infected cattle. $T$ cell activation was determined by measuring $\gamma$-interferon released from PBMC incubated with extracts of $E$. coli(pMBA21). Samples from three infected and three healthy animals were taken. The values $\left(\mathrm{OD}_{450}\right)$ were $0 \cdot 39,2 \cdot 1$ and 0.81 for three infected animals and $0 \cdot 02,0.05$ and 0.18 for three healthy animals. On average the $\gamma$-interferon release was four times higher in assays with samples from infected cattle than in samples from healthy cattle.

\section{Presence of P27 in other mycobacteria}

To determine which mycobacterial species have the gene encoding P27, we performed PCR analysis using specific primers for this gene (Fig. 6), amplifying a $1 \cdot 1 \mathrm{~kb}$ fragment. Only the members of the M. tuberculosis complex showed a strong amplification band. The $M$. vaccae, $M$. paratuberculosis and $M$. avium complex gave a faint amplification band. $M$. kansasii showed amplification bands of 1.8 and $1.0 \mathrm{~kb}$. M. smegmatis, $M$. marinum, M. gordonae, $M$. aureum and $M$. scrofulaceum showed no amplification.

\section{DISCUSSION}

An important effort has been directed toward the characterization of mycobacterial secreted proteins because they were reported as protective antigens (Orme, 1988; Pal \& Horwitz, 1992) and as the main target of the $T$ cell response (Andersen et al., 1995). Less attention has been paid to membrane protein antigens. In this paper we describe a $27 \mathrm{kDa}$ membrane protein of $M$. bovis found by molecular cloning procedures. The entire coding region of the gene encoding P27 was cloned and sequenced. Two possible start codons could be postulated. We favour the second ATG codon because it is the only one presenting a putative ribosome-binding sequence. The amino acid sequence deduced from the gene sequence indicated that the protein has a molecular mass of $24.5 \mathrm{kDa}$. After signal sequence processing, the mature protein should have a molecular mass of $21.7 \mathrm{kDa}$. The discrepancy between the molecular mass of the sequence-deduced protein and that determined by PAGE could be due to hypothetical post-translational modifications or to the high proline content that may alter its electrophoretic behaviour. Other mycobacterial proteins show a similar irregular migration (Prestidge $e t$ al., 1995).

A $35 \mathrm{kDa}$ protein was also recognized by cattle and rabbit sera in recombinant $E$. coli. It is not encoded by pMBA21, because the $35 \mathrm{kDa}$ protein was also detected in $E$. coli transformed with the shortened derivative pMBA23. While we have not performed experiments to clarify the nature of this protein, it may arise by the formation of a multimer between an E. coli protein and $\mathrm{P} 27$, as the $35 \mathrm{kDa}$ protein is not observed in mycobacterial extracts.

Sequence analysis revealed that $\mathrm{P} 27$ has the consensus pattern for prokaryotic lipoprotein modification. According to studies in lipoproteins from other bacteria, a cysteine residue is the site of proteolytic processing and acylation by a type II signal peptidase (von Heijne, 1989; Mattar et al., 1994). Subcellular fractionation and phase separation with Triton X-114 suggested that P27 is an integral membrane protein. This result is in agreement with the hydrophobic domains observed in the P27 amino acid sequence. It is important to note that Young \& Garbe (1991) identified, without further characterization, a $27 \mathrm{kDa}$ lipoprotein in M. tuberculosis. The $19 \mathrm{kDa}$ protein (Faith et al., 1991; Young \& Garbe, 1991), P38 (Harboe \& Wiker, 1992) and MPB83 (Hewinson et al., 1996; Wiker et al., 1996; Matsuo et al., 1996) are examples of well-characterized mycobacterial lipoproteins. These differ from P27 in that they are also found in the culture supernatant (Fifis et al., 1990; Harboe \& Wiker, 1992), while we could not find P27 in culture supernatant, even when we used 8-week-old cultures (data not shown). While the function of the $19 \mathrm{kDa}$ protein remains unknown, P38 is a component of the M. tuberculosis phosphate transport system. At the present state of our research it is difficult to speculate about the possible function of P27.

The antigenicity of P27 was demonstrated by the fact that 4 of 7 sera from cattle naturally infected with $M$. bovis recognized the recombinant protein. Preliminary experiments with bovine lymphocytes also showed $T$ cell reactivity toward P27. The $19 \mathrm{kDa}$ and the P38 lipoproteins are relevant antigens (Faith et al., 1991; Young \& Garbe, 1991; Harboe \& Wiker, 1992). Lipoproteins may be important in directing cell-mediated immune responses. For example, acylation has been found to enhance the ability of protein antigens to induce delayed type hypersensitivity responses (Coon \& Hunter, 1975) and it has been demonstrated that 
synthetic lipopeptides have the ability to prime cytotoxic T lymphocytes in vivo (Deres et al., 1989).

The gene sequence was found to be identical to that of a hypothetical $27 \mathrm{kDa}$ protein gene found in the $M$. tuberculosis genome sequencing project achieved by the Sanger Centre (Cambridge, UK). According to their data (and partially ours) the gene encoding P27 and that of a protein of $55 \mathrm{kDa}$ could form an operon. The $55 \mathrm{kDa}$ protein is postulated to be involved in drug resistance, because it has homology with a Streptomyces coelicolor actinorhodin transporter. Further experiments, such as Northern blotting, will be needed to elucidate whether both genes form an operon. Interestingly, the $S$. coelicolor gene homologous to P27 has an upstream ORF encoding a putative $20 \mathrm{kDa}$ protein. This fact could suggest a similar genome organization in both species. Another M. tuberculosis hypothetical gene, encoding a $26.4 \mathrm{kDa}$ protein, also deduced from the M. tuberculosis genome sequencing project (but in a different cosmid from that of the gene encoding P27), showed partial homology to P27. The homology is stronger in some portions of the two proteins. The putative $26.4 \mathrm{kDa}$ protein sequence lacks the consensus signature for a lipoprotein. Both proteins may form an antigenic family, but presently we do not know if our sera also recognizes the $26.4 \mathrm{kDa}$ protein.

PCR experiments suggested that only $M$. tuberculosis complex strains have the gene encoding P27. The $M$. vaccae, $M$. paratuberculosis and $M$. avium complex strains gave rise to a faint amplification band, suggesting that a homologous gene exists in these species. Other mycobacteria tested showed no amplification. However, these bacteria may have genes similar to P27 with divergent sequences in the primer binding site.

In conclusion, a novel antigenic membrane protein of M. tuberculosis/M. bovis was identified. It is a putative lipoprotein. As the lipid moiety is described to enhance antigenicity, it would be interesting to study the function of lipidation in the antigenicity of P27. This study may be useful in the development of subunit vaccines against tuberculosis. We also hope that further studies on this and other membrane proteins will contribute to the comprehension of $M$. bovis/M. tuberculosis-host interaction.

\section{ACKNOWLEDGEMENTS}

This work was supported by the International Foundation for Science (Stockholm, Sweden). The valuable suggestions of Mariana Del Vas and Oscar Taboga are gratefully acknowledged. A.C. and M.I.R. are fellows of the National Research Council of Argentina (CONICET).

\section{REFERENCES}

Abou-Zeid, C., Smith, I., Grange, J., Ratliff, T., Steele, J. \& Rook, G. (1988). The secreted antigens of Mycobacterium tuberculosis and their relationship to those recognized by the available antibodies. J Gen Microbiol 134, 531-538.
Andersen, A. B. \& Brennan, P. (1994). Protein and antigens of Mycobacterium tuberculosis. In Tuberculosis: Pathogenesis, Protection and Control, pp. 307-332. Edited by B. Bloom. Washington, DC: American Society for Microbiology.

Andersen, P. (1994). Effective vaccination of mice against Mycobacterium tuberculosis infection with a soluble mixture of secreted mycobacterial proteins. Infect Immun 62, 2536-2544.

Andersen, P., Askgaard, D., Ljungqvist, L., Bennedsen, J. \& Heron, I. (1991). Proteins released from Mycobacterium tuberculosis during growth. Infect Immun 59, 1905-1910.

Andersen, P., Andersen, A. B., Sorenssen, A. L. \& Nagai, S. (1995). Recall of long lived immunity to Mycobacterium tuberculosis infection in mice. J Immunol 154, 3359-3372.

Ashbridge, K. R. (1989). Nucleotide sequence of the $19 \mathrm{kDa}$ antigen gene from Mycobacterium tuberculosis. Nucleic Acids Res 17, 1249.

Bigi, F., Alito, A., Romano, M. I. \& Cataldi, A. (1995). Characterization of a novel Mycobacterium bovis secreted antigen containing PGLTS repeats. Infect Immun 63, 2581-2586.

Booth, R. J., Williams, D. L., Mougdil, K. D., Noonan, L. C., Grandison, P. M., McKee, J. J., Prestidge, R. L. \& Watson, J. D. (1993). Homologs of the Mycobacterium leprae 18-kilodalton and Mycobacterium tuberculosis 19-kilodalton antigens in other mycobacteria. Infect Immun 61, 1509-1515.

Bordier, C. (1981). Phase separation of integral membrane proteins in triton X-114 solution. J Biol Chem 256, 1604-1607.

Cataldi, A. A., Romano, M. I. \& Bigi, F. (1994). A western blot study of $M$. bovis antigens recognized by cattle sera. Res Microbiol 145, 689-698.

Collins, M. E., Patki, A., Wall, S., Nolan, A., Goodger, J., Woodward, M. J. \& Dale, J. W. (1990). Cloning and characterization of the gene for the $19 \mathrm{kDa}$ antigen of Mycobacterium bovis. $J$ Gen Microbiol 136, 1429-1436.

Coon, J. \& Hunter, R. (1975). Properties of conjugated protein immunogens which selectively stimulated delayed type hypersensitivity. J Immunol 114, 167-169.

Deres, K., Schild, H., Wiesmuller, K.-H., Jung, G. \& Rammensee, H.-G. (1989). In vivo priming of virus-specific cytotoxic Tlymphocytes with synthetic lipopeptide vaccine. Nature 342, 561-564.

Faith, A., Moreno, C., Lathigra, R., Roman, E., Fernandez, M., Brett, S., Mitchell, D. M., Ivanyi, J. \& Rees, D. M. (1991). Analysis of human $\mathrm{T}$ cell epitopes in the $19,000 \mathrm{MW}$ antigen of Mycobacterium tuberculosis, influence of HLA-DR. Immunology 74, 1-7.

Fifis, T. C., Costopoulos, C., Radford, A. J., Bacic, A. \& Wood, P. R. (1990). Purification and characterization of major antigens from Mycobacterium bovis culture filtrate. Infect Immun 59, 800-807.

Harboe, M. \& Wiker, H. (1992). The $38-\mathrm{kDa}$ protein of $\mathrm{Myco}$ bacterium tuberculosis: a review. J Infect Dis 166, 874-884.

von Heijne, G. (1989). The structure of signal peptides from bacterial lipoproteins. Protein Eng 2, 531-534.

Hewinson, R. G., Michell, S. L., Russell, W. P., Mcadam, R. A. \& Jacobs, W. R. (1996). Molecular characterization of MPT83: a seroreactive antigen of Mycobacterium tuberculosis with homology to MPT70. Scand J Immunol 43, 490-499.

Ivanyi, J., Morris, J. A. \& Keen, M. (1985). Studies with monoclonal antibodies to mycobacteria. In Monoclonal Antibodies Against Bacteria Vol. 1, pp. 59-69. Edited by A. J. L. Macario \& E. Conway de Macario. Orlando, FL: Academic Press. 
Kyhse-Andersen, J. (1984). Electroblotting of multiple gels, a simple apparatus without buffer tank for rapid transfer of proteins from polyacrylamide to nitrocellulose. J Biochem Biophys Methods 10, 203-209.

Kyte, J. \& Doolittle, R. F. (1982). A simple method for displaying the hydropathic character of a protein. J Mol Biol 157, 105-132.

Laemmli, U. K. (1970). Cleavage of structural proteins during the assembly of the head of bacteriophage T4. Nature 227, 680-685.

Lee, B. Y., Hefta, S. A. \& Brennan, P. (1991). Characterization of the major membrane protein of virulent. Mycobacterium tuberculosis. Infect Immun 60, 2066-2074.

Marck, C. (1988). DNA Strider: a C program for the Apple Macintosh. Nucleic Acids Res 16, 1829-1836.

Matsuo, T., Matsuo, H., Ohara, N., Matsumoto, S., Kitaura, H., Mizuno, A. \& Yamada, T. (1996). Cloning and sequencing of an MPB70 homologue corresponding to MPB83 from Mycobacterium bovis BCG. Scand J Immunol 43, 483-489.

Mattar, S., Scharf, B., Kent, S. B. H., Rodewald, K., Oesterhelt, D. \& Engelhard, M. (1994). The primary structure of halocyanin, an archaeal blue copper protein, predicts a lipid anchor for membrane fixation. J Biol Chem 269, 14939-14945.

Orme, I. (1988). Induction of nonspecific acquired resistance and delayed type hypersensitivity, but not specific acquired resistance, in mice inoculated with killed mycobacterial vaccines. Infect Immun 56, 3310-3312.

Pal, P. G. \& Horwitz, M. A. (1992). Immunization with extracellular proteins of Mycobacterium tuberculosis induces cell mediated immune responses and substantial protective immunity in a guinea pig model of pulmonary tuberculosis. Infect Immun $58,4781-4792$.

Prestidge, R. L., Grandison, P. M., Chuck, D. W. W., Booth, R. J. \& Watson, J. D. (1995). Production of the $19-\mathrm{kDa}$ antigen of Mycobacterium tuberculosis in Escherichia coli and its purification. Gene 164, 129-132.

Sambrook, J., Fritsch, E. F. \& Maniatis, T. (1989). Molecular Cloning: a Laboratory Manual, 2nd edn. Cold Spring Harbor, NY: Cold Spring Harbor Laboratory.
Sanger, F., Nicklen, S. \& Coulson, A. R. (1977). DNA sequencing with chain-terminating inhibitors. Proc Natl Acad Sci USA 74, $5463-5467$.

van Soolingen, D., Hermans, P. W. M., de Haas, P. E. W., Soll, D. R. \& van Embden, J. D. A. (1991). Occurrence and stability of insertion sequences in Mycobacterium tuberculosis complex strains: evaluation of an insertion sequence dependent DNA polymorphism as a tool in the epidemiology of tuberculosis. $J$ Clin Microbiol 29, 2578-2586.

Verbon, A., Kuijper, S., Jansen, H. M., Peelman, P. \& Kolk, A. H. J. (1990). Antigens in culture supernatant of Mycobacterium tuberculosis : epitopes defined by monoclonal and human antibodies. J Gen Microbiol 136, 955-964.

Wiker, H. G., Harboe, M. \& Nagai, S. (1991). A localization index for distinction between extracellular and intracellular antigens of Mycobacterium tuberculosis. J Gen Microbiol 137, 875-884.

Wiker, H. G., Nagai, S., Hewinson, R. G., Russell, W. P. \& Harboe, M. (1996). Heterogeneous expression of the related MBP70 and MPB83 proteins distinguish various substrains of Mycobacterium bovis BCG and Mycobacterium tuberculosis H37rv. Scand J Immunol 43, 374-380.

Young, D. \& Garbe, T. R. (1991). Lipoprotein antigens of Mycobacterium tuberculosis. Res Microbiol 142, 55-65.

Young, D. B., Garbe, T., Lathigra, R. \& Abou-Zeid, C. (1990). Proteins antigens: structure, function and regulation. In Molecular Biology of the Mycobacteria, pp. 1-35. Edited by J. McFadden. London: Surrey University Press.

Young, D. B., Kaufmann, S. H. E., Hermans, P. W. M. \& Thole, J. E. R. (1992). Mycobacterial protein antigens: a compilation. Mol Microbiol 6, 133-145.

Young, R. A., Bloom, B. R., Grosskinsky, C. M., Ivanyi, J., Thomas, D. \& Davis, R. W. (1985). Dissection of Mycobacterium tuberculosis antigens using recombinant DNA. Proc Natl Acad Sci USA 82, 2583-2587.

Received 3 June 1997; revised 1 August 1997; accepted 5 August 1997. 